\title{
РЕАЛІЗАЦІЯ ПРИНЦИПУ РОЗВИТКОВОСТІ У МОДУЛЬНО-РОЗВИВАЛЬНІЙ ВЗАЕМОДІЇ ЧЕРЕЗ ІННОВАЦІЙНІ ТЕХНОЛОГІЇ В ЗАКЛАДАХ ВИЩОЇ ОСВІТИ
}

\begin{abstract}
У статті розглянуто процес реалізації принципу розвитковості в модульно-розвивальній взаємодії через інновачійні технології в умовах закладів вищої освіти. Автором зазначено, щзо в умовах сьогодення прочес модульнорозвивальної взаємодї характеризується різновидом практик педагогічного досвіду, інновачійної дидактичної системи, а також розвитком наукової теорії. Публікація розкриває актуальність освітньої функиії, щзо полягає в розвитку кожної людини. Підкреслено, щуо саме освіта забезпечує наявність знань про суспільство й природу; в проиесі освітньої взаємодї̈ людина набуває комунікативного, розумового й емочійного досвіду. Взаємодія в освітньому прочесі, як підкреслює автор, забезпечує людину готовністю до життя в умовах сочіально-економічного й науково-технічного прогресу; до планування особистого життя на основі ідеалів, відбувається формування моральних та естетичних иінностей сучасного суспільства. Відповідно, модульно-розвивальна взаємодія передбачає наявність наукової теорії для визначення ідей і принципів, законів $і$ закономірностей, понять $і$ наукових фактів розвитку суб 'єктів взаємодї̈ в трьох аспектах: інформаційно-пізнавальному, нормативно-регуляційному й иіннісно-естетичному. У такому контексті схарактеризовано інноваційну педагогічну технологію як структуровану сукупність прийомів і методів, щчо спрямовані на вивчення, актуалізацію та оптимізаџію інноваційної педагогічної діяльності.

У матеріалах також викладено теоретичний аналіз сутності інноваційних технологій у сфері освіти. Представлений аналіз досліджень доводить, щзо використання інновачійних педагогічних технологій сприяє залученню здобувачів вищсої освіти, покращує їхнє критичне й креативне мислення, а також знижує апатію та сприяє навчанню одногрупників.

На основі аналізу наукового досвіду украӥнських і зарубіжни учених з 'ясовано перелік технологій, застосування яких уможливить реалізацію принцииу розвитковості в модульно-розвивальній взаємодї. Автором виокремлено такі інноваційні технології, як технологія дистанційного навчання; технологія проєктування; технологія розвитку критичного мислення, щзо заплановано використати в подальшому експериментальному дослідженні.

Ключові слова: принцип розвитковості, інноваційні технологї̈ у вищій освіті, модульно-розвивальна взаємоdiя.
\end{abstract}

\section{Alla SENYK, \\ orcid.org/0000-0002-6217-7464 \\ Candidate of Pedagogical Sciences, \\ Lecturer at the Department of Psychology and Social Work \\ West Ukrainian National University \\ (Ternopil, Ukraine) allisiya@gmail.com}

\section{IMPLEMENTATION OF THE PRINCIPLE OF DEVELOPMENT IN MODULAR-DEVELOPMENT INTERACTION THROUGH INNOVATIVE TECHNOLOGIES IN HIGHER EDUCATION INSTITUTIONS}

The article considers the process of realization of the principle of development in modular-developmental interaction through innovative technologies in the conditions of higher education institutions. The author notes that in today's conditions the process of modular-developmental interaction is characterized by a variety of practices of pedagogical experience, innovative didactic system, as well as the development of scientific theory. The publication reveals the relevance of the educational function, which is the development of each person. It is emphasized that it is education that ensures the availability of knowledge about society and nature; in the process of educational interaction a person acquires communicative, mental and emotional experience. Interaction in the educational process provides a person with readiness for life in terms of socio-economic and scientific and technological progress; to the planning of personal life on the basis of ideals, there is a formation of moral and aesthetic values of modern society. Accordingly, modular-developmental 
interaction presupposes the existence of scientific theory to define ideas and principles, laws and regularities, concepts and scientific facts of development of subjects of interaction in three aspects: information-cognitive, normative-regulatory and value-aesthetic. In this context, innovative pedagogical technology is characterized as a structured set of techniques and methods aimed at studying, updating and optimizing innovative pedagogical activities. The materials cover the theoretical analysis of the essence of innovative technologies in the field of education. The presented analysis of research proves that the use of innovative pedagogical technologies helps to attract students of higher education, improves their critical and creative thinking, as well as reduces apathy and promotes the learning of classmates.

Based on the analysis of the scientific experience of Ukrainian and foreign scientists, the list of technologies, the application of which will allow the implementation of the principle of development in modular development. Also, in the course of the research, such innovative technologies as distance learning technology were singled out for conducting experimental study; design technology; technology for the development of critical thinking.

Key words: principle of development, innovative technologies in higher education, modular development interaction.

Постановка проблеми. Трансформація освіти від установки на трансляцію готового знання до спільного відкриття нових наукових положень змушує педагогів перебувати в пошуку шляхів оптимізації багатоскладних процесів соціально-особистісного росту учасників педагогічної взаємодії. У сучасних умовах модернізації освітнього процесу модульно-розвивальна взаємодія характеризується різновидом практики, що інтенсивно розвивається, наприклад, педагогічний досвід, інноваційна дидактична система, а також наукова теорія.

3 приводу педагогічного досвіду зазначимо на доцільності об'єднання декількох закладів освіти для формування відповідних модулів у контексті традиційної освітньої практики (від закладів середньої освіти до закладів вищої освіти).

Щодо модульно-розвивальної взаємодії як інноваційної дидактичної системи, варто вказати про сукупність цілей, змісту, форм, методів і засобів, що забезпечують оптимізацію співпраці викладача й здобувачів вищої освіти завдяки реалізації проблемності й модульності. Водночас модульно-розвивальна взаємодія передбачає наявність наукової теорії для визначення ідей і принципів, законів і закономірностей, понять і наукових фактів розвитку суб'єктів взаємодії в трьох аспектах: інформаційно-пізнавальному, нормативно-регуляційному й ціннісно-естетичному.

Аналіз досліджень. Теоретичний аналіз сутності інноваційних технологій у сфері освіти; моделювання характеристик інноваційних технологій (технологія дистанційного навчання; технологія проєктування; технологія розвитку критичного мислення) на основі опрацьованих праць українського (Т. Гурова, С. Гуров, Л. Москальова, М. Михайліченко, Я. Рудик та інші) й зарубіжного досвіду (Худа Міфтачул, Хашим Азміл, Камарул Шукри Мат Тех, К. Шанкар, Дж. Сантос, А. Сімос Фіджідоб, М. Вієра, К. Кедраки й Дж. Ротіді й інші), застосування яких уможливить реалізацію принципу розвитковості в модульно-розвивальній взаємодії (А. Гірняк, Ф. Фурман та інші).
Мета статті полягає в розкритті актуальності освітньої функції, що полягає в розвитку кожної людини й 3'ясуванні переліку технологій, що уможливлять реалізацію принципу розвитковості в модульно-розвивальній взаємодії.

Виклад основного матеріалу. Інновації в освіті нерозривно пов'язані із загальними процесами в суспільстві. В усі часи освіта була зосередження на виконання провідної функції, що полягала в розвитку кожної людини. Саме освіта забезпечує наявність знань про суспільство й природу; в процесі освітньої взаємодії людина набуває комунікативного, розумового й емоційного досвіду. Взаємодія в освітньому процесі забезпечує людину готовністю до життя в умовах соціально-економічного й науково-технічного прогресу; до планування особистого життя на основі ідеалів відбувається формування моральних та естетичних цінностей сучасного суспільства.

Специфічними особливостями здобуття інноваційної освіти є відкритість здобувачів вищої освіти; здатність суб'єктів освіти до передбачення на основі постійного моніторингу означеного процесу; налаштованість на конструктивні дії в будьяких ситуаціях.

Сутність поняття «інноваційна педагогічна технологія» характеризується структурованою сукупністю прийомів і методів, що спрямовані на вивчення, актуалізацію та оптимізацію інноваційної педагогічної діяльності. I, відповідно, в результаті інноваційної діяльності відбуваються якісні зміни в освіті, що потребують моніторингу доцільності нововведень із метою передбачення позитивних і негативних наслідків впливу.

У працях А. Гірняка, А. Фурмана наголошується на тому, що модульно-розвивальна система повно реалізує конструктив чотирьох принципів, а саме: ментальності, духовності, розвитковості й модульності в єдності змісту, наступності структури й цілісності наукового описання освітнього процесу (Фурман, 2018), (Гірняк, 2020).

Публікацію присвячено розгляду технологій, використання яких уможливить підвищення 
рівня модульно-розвивальної взаємодії в закладах вищої освіти саме в контексті принципу розвитковості (розвитку).

Нам імпонує думка А. Гірняка 3 приводу можливостей використання інноваційних освітніх технологій для керівництва не лише міжсуб'єктними взаємостосунками, а й психічною активністю здобувачів вищої освіти (Гірняк, 2020). Учений акцентує на розробленні авторських програм і методик, що, на наш погляд, $є$ зручним у виборі інноваційних технологій і побудові індивідуальної траєкторії як для професійної діяльності викладача, так і для освітнього процесу здобувача вищої освіти.

У переліку інноваційних технологій (за М. Михайліченком, Я. Рудиком) вказано такі:

- технологія критичного мислення, що полягає у формуванні власної думки в здобувача вищої освіти, в навчанні його впевнено вести дискусії та приймати виважені рішення, в сприянні засвоєнню навичок самостійно здобувати знання, вчитись відкрито спілкуватись, логічно мислити й аргументувати;

- технологія навчання як дослідження має за мету прищепити здобувачам вищої освіти навички науково-дослідної роботи, формуючи творчоактивну особистість;

- інтегральна педагогічна технологія створює оптимальні умови для розвитку й самореалізації здобувачів вищої освіти в процесі формування цілісних знань про об'єкт, що вивчається та який $\epsilon$ основою творення «образу світу»;

- технологія розвивального навчання формує в здобувачів вищої освіти здібності до самовдосконалення, активного, самостійного творчого мислення та самостійного навчання;

- технології формування творчої особистості сприяють набуттю вмінь приймати неординарні рішення, свідомо обирати власну життєву позицію, генерувати оригінальні ідеї;

- технологія особистісно орієнтованого навчання має на меті надати здобувачам вищої освітиможливостісамостійномислити,демонструвати незалежність у здійсненні власного вибору;

- проєктна технологія націлена на стимулювання інтересу здобувачів вищої освіти до здобуття нових знань і до саморозвитку;

- технологія диференційованого навчання формує в здобувачів уміння вчитися, відчувати потребу в самоосвіті, виявляти бажання до генерації нових ідей і пошуку альтернативних рішень у проблемних ситуаціях;

- технологія гуманістичного навчання спрямована на виховання свідомих громадян, патріотів, освічених, творчих особистостей;
- технологія модульно-розвивального навчання формує самоосвітню компетентність здобувачів вищої освіти;

- технологія групового навчання формує внутрішню мотивацію здобувачів до активного сприйняття та комунікативності;

- технології індивідуалізації процесу навчання забезпечують максимальну продуктивність роботи здобувачів у наявній освітній системі (Михайліченко, 2016).

3 метою визначення переліку оптимальних інноваційних технологій сучасності проаналізуємо український і зарубіжний науковий досвід. Беручи до уваги те, що модульно-розвивальна взаємодія між викладачем і здобувачами вищої освіти має бути безперервною та обов'язково враховувати соціально-економічний стан країни, ми звернули увагу на питання електронної освіти. Сучасне суспільство потребує високорозвинених фахівців, які здатні працювати в умовах технічних змін, а отже, використання інновацій в освіті $є$ поштовхом до економічного зростання та соціального розвитку. Так, наприклад, вчені Малайзії Міфтачул Худа, Азміл Хашим, Камарул Шукри Мат Тех, К. Шанкар та інші (Miftachul Huda, 2019) вважають, що сучасне освітнє середовище надає можливість інтеграції педагогічних навичок та адаптивних технологій (з урахуванням цифрової ери й мультимодального стилю навчання). Освітній процес XXI ст., на їх думку, характеризується віртуальністю та віддаленістю, а тому має базуватися на розвитку критичного мислення, що своєю чергою можливо за умови використання технологій дистанційного або онлайн навчання.

Позитивний український досвід використання інноваційних технологій на прикладі технології інтерактивного навчання представлено в дослідженнях Т. Гурової, С. Гурова й Л. Москальової (Gurova, 2017). Розвиток міжкультурної комунікативної компетенції здобувачів вищої освіти, як вважають вчені, відбувається саме завдяки створеним умовам для успішної взаємодії між викладачем і здобувачами (наприклад, такі інтерактивні вправи: «Різне сприйняття», «Культурна традиція», «Ідіоми й прислів'я», «За і проти», «Чи знаєте ви людину?» тощо).

Принцип розвитковості в модульно-розвивальній взаємодії та його реалізація через інноваційні технології простежується в працях португальських вчених. Так, Дж. Сантос, А. Сімос Фіджідоб, М. Biєра (Santosa, 2019), визначаючи стратегічні настанови, що сприяють концептуальній зміні у вищій школі, в контекст підходів до викла- 
дання, орієнтованих на здобувачів вищої освіти, виділили чотири технології:

- дисонанс між концепціями й підходами до викладання;

- змішані підходи щодо застосування інформаційно-комунікаційних технологій;

- цифрове моделювання;

- технології, що застосовуються для великих груп здобувачів (використання онлайн інструментів; віртуальних наставників та інквізитори; опитування на виході тощо).

Проте, аналізуючи наявну систему дистанційної освіти в Україні (І. Івженко, І. Сокіл, В. Кохіна, М. Носкова, Л. Єрьоміна), викладають як позитивні сторони (гнучкість, паралельне навчання, далекі дії, асинхронність, масовість, інтернаціональність, модульність, поширення інноваційних технологій і зняття соціальної напруги тощо), так і негативні (низький рівень технологічної та інноваційної підтримки, відсутність роботи в команді й соціальної взаємодії, потреба в комп'ютерному навчанні для участі в дистанційній освіті, а також відсутність сучасного програмного забезпечення) (Ivzhenko, 2020). Уважаємо, що завдяки спільним зусиллям українські освітяни здатні подолати вказані труднощі, адже опрацьовані матеріали досліджень як українських, так і зарубіжних вчених доводять, що використання інноваційних педагогічних технологій сприяє залученню здобувачів вищої освіти, покращує їх критичне й креативне мислення, а також знижує апатію та сприяє навчанню одногрупників.

Схожі погляди мають грецькі вчені К. Кедраки й Дж. Ротіді (Katerina Kedraka \& Georgia Rotidi, 2017), які, розглядаючи вищу освіту як складну картину, що об'єднує педагогічні навички, емоційну взаємодію між викладачем і здобувачами вищої освіти й сучасні технології, наголошують на важливості переходу викладацької діяльності від «що» до «як і чому». У такому контексті, на думку вчених, доречне застосування технології критичного навчання (мислення).

Як бачимо, сучасні заклади вищої освіти в рамках інноваційної діяльності мають створювати, сприймати, реалізовувати нововведення та своєчасно позбавлятися від застарілого й педагогічно недоцільного. Усе це можливе за умови творчих прагнень професорсько-викладацького колективу та їх ставлень до нововведень.

Висновки. На підставі проведеного аналізу сутності інноваційних технологій та їх використання у вищій школі вважаємо за доцільне виокремити такі:

- технологія дистанційного навчання - інтерактивна взаємодія між викладачем, здобувачами вищої освіти й інтерактивним джерелом інформаційного ресурсу (наприклад, Web-сайту або Webсторінки), що містить усі компоненти навчального процесу (мета, зміст, методи, організаційні форми, засоби навчання). Модульно-розвивальна взаємодія відбувається через комп'ютерну візуалізацію освітнього матеріалу, архівне зберігання інформації, іiі передачу й обробку завдяки організаційному управлінню освітньою діяльністю та контролю результатів засвоєння матеріалу;

- технологія проєктування - варіант продуктивної освіти, що базується на сукупності ідей, документів, текстів для створення теоретичного або практичного продукту (типи проєктів: творчі, ігрові, інформаційні,практико-орієнтованійдослідницькі);

- технологія розвитку критичного мислення здатність до чіткого виділення проблеми: обробка, аналіз та аргументація (формування пізнавального інтересу здобувачів; внутрішня мотивація; спонукання до порівняння отриманої інформації з власним досвідом і формування відповідного аналітичного судження). До характеристик критичного мислення належить самостійність (мислення стає критичним лише за умови індивідуальності); постановка проблеми; прийняття рішення; чітка аргументованість і соціальність (комунікативні навички для поглиблення або зміни власної позиції).

Перспективу подальших наукових досліджень вбачаємо в експериментальній перевірці ефективності вказаних технологій у модульно-розвивальній взаємодії серед здобувачів вищої освіти Тернопільського національного економічного університету.

\section{СПИСОК ВИКОРИСТАНИХ ДЖЕРЕЛ}

1. Гірняк А. Психологічні детермінанти модульно-розвивальної взаємодії учасників інноваційного навчання. Вісник ХНПУ імені Г. С. Сковороди. Серія «Психологія». 2020. № 62. С. 37-50.

2. Михайліченко М., Рудик Я. Освітні технології : навчальний посібник. Київ : ЦП «КОМПРИНТ», 2016. 583 с.

3. Фурман А., Гірняк A. Psychological technology of the interaction between teacher and students under the conditions of innovative module-developmental teaching. Гуманітарний вісник ДВНЗ «Переяслав-Хмельницький державний педагогічний університет ім. Григорія Сковороди». 2018. Вип. 37 (4). Том I (23). С. 123-135.

4. Gurova T., Gurov S., Moskaliova L. Innovative technologies in the formation of future english teachers' intercultural communicative competence. Наука і освіта. Державний заклад Південноукраӥнський наиіональний педагогічний університет імені К. Д. Уиинського. 2017. № 6. С. 44-50. 
5. Ivzhenko I., Sokol I., Kochyna V., Noskova M., Yeromina L. Development and application of innovative technologies in the process of remote education of Ukraine. JCR. 2020. № 7 (12) P. 1251-1253.

6. Katerina Kedraka \& Georgia Rotidi. University Pedagogy: A New Culture is Emerging in Greek Higher Education. International Journal of Higher Education. 2017. Vol. 6. No. 3. P. 147-153.

7. Miftachul Huda, Azmil Hashim, Kamarul Shukri Mat Teh, K. Shankar, B. Ayshwarya, Phong Thanh Nguyen, Wahidah Hashim, Andino Maseleno. Learning Quality Innovation through Integration of Pedagogical Skill and Adaptive. Technology International Journal of Innovative Technology and Exploring Engineering (IJITEE). 2019. Volume 8. Issue 9S3. P. $1538-1541$.

8. Santosa J., Figueiredob A. S., Vieira M. Innovative pedagogical practices in higher education: An integrative literature review. Nurse Education Today. 2019. № 72. P. 12-17.

\section{REFERENCES}

1. Hirniak, A. (2020). Psykholohichni determinanty modulno-rozvyvalnoi vzaiemodii uchasnykiv innovatsiinoho navchannia [Psychological determinants of modular-developmental interaction of participants in innovative education] Visnyk KhNPU imeni H. S. Skovorody "Psykholohiia" [in Ukrainian].

2. Mykhailichenko, M., Rudyk, Ya. (2016). Osvitni tekhnolohii: navchalnyi posibnyk [Educational technologies: tutorial]. K.: TsP "KOMPRYNT" [in Ukrainian].

3. Furman, A., Hirniak, A. (2018). Psychological technology of the interaction between teacher and students under the conditions of innovative module-developmental teaching. Humanitarnyi visnyk DVNZ "Pereiaslav-Khmelnytskyi derzhavnyi pedahohichnyi universytet im. Hryhoriia Skovorody" [in English].

4. Gurova, T., Gurov, S., Moskaliova, L. (2017). Innovative technologies in the formation of future english teachers intercultural communicative competence. Nauka i osvita. Derzhavnyi zaklad Pivdennoukrainskyi natsionalnyi pedahohichnyi universytet imeni KD Ushynskoho [in English].

5. Ivzhenko, I., Sokol, I., Kochyna, V., Noskova, M., Yeromina, Liliia (2020). Development and application of innovative technologies in the process of remote education of Ukraine. JCR. 7(12): 1251-1253 [in English].

6. Katerina Kedraka \& Georgia Rotidi. (2017). University Pedagogy: A New Culture is Emerging in Greek Higher Education. International Journal of Higher Education Vol. 6, No. 3; 147-153 [in English].

7. Miftachul, Huda, Azmil, Hashim, Kamarul Shukri Mat Teh, K. Shankar, B. Ayshwarya, Phong Thanh Nguyen, Wahidah Hashim, Andino Maseleno (2019). Learning Quality Innovation through Integration of Pedagogical Skill and Adaptive. Technology International Journal of Innovative Technology and Exploring Engineering (IJITEE), Volume-8, Issue-9S3, 1538-1541[in English].

8. Santosa, J., Figueiredob, A. S., Vieira, M. (2019). Innovative pedagogical practices in higher education: An integrative literature review. Nurse Education Today [in English].

9. Ivzhenko, I., Sokol, I., Kochyna, V., Noskova, M., Yeromina, L. (2020). Development and application of innovative technologies in the process of remote education of Ukraine. JCR. [in English]. 